Regards sur l'économie allemande

Bulletin économique du CIRAC

$114 \mid 2014$

Varia

\title{
Réseaux sociaux
}

Social Business - Von Communities und Collaboration, Social Media auf dem Weg ins Unternehmen, Praxisorientierter Leitfaden

\section{(2) OpenEdition}

Journals

Édition électronique

URL : http://journals.openedition.org/rea/4741

DOI : $10.4000 /$ rea.4741

ISSN : 1965-0787

Éditeur

CIRAC

Édition imprimée

Date de publication : 1 octobre 2014

Pagination : 44

ISSN : 1156-8992

Référence électronique

"Réseaux sociaux », Regards sur l'économie allemande [En ligne], 114 | octobre 2014, mis en ligne le 01 octobre 2014, consulté le 22 septembre 2020. URL : http://journals.openedition.org/rea/4741 ; DOI : https://doi.org/10.4000/rea.4741

Ce document a été généré automatiquement le 22 septembre 2020

(C) CIRAC 


\section{Réseaux sociaux}

Social Business - Von Communities und Collaboration, Social Media auf dem Weg ins Unternehmen, Praxisorientierter Leitfaden

\section{RÉFÉRENCE}

ATCHISON Annabelle, MICKELEIT Thomas, ROSSI Carsten (Hg.), Social Business - Von

Communities und Collaboration, Social Media auf dem Weg ins Unternehmen, Praxisorientierter Leitfaden, Frankfurter Allgemeine Buch, Francfort/Main, 2014, 312 p.

1 Les médias sociaux tels Facebook, Twitter et YouTube ont radicalement transformé notre façon de communiquer. De plus en plus, les entreprises s'en inspirent et mettent en place des plates-formes pour stimuler les échanges en interne et avec les clients, ou encore pour accélérer les process innovants. Les contributeurs de ce livre - managers, conseillers en communication et chercheurs - livrent des clés pour y parvenir. (Solène Hazouard) 